\title{
JENIS DAN KOMPONEN ARTIKEL ILMIAH (BAGIAN 2)
}

Sitti Syabariyah*

\begin{abstract}
Abstrak
Jenis tulisan dibedakan atas jenis tulisan yang memuat fakta, peristiwa dan proses (yang disebut feature); tulisan yang berisi pendapat (yang disebut kolom opini); dan tulisan yang berisi sikap dan pendirian subjektif penulis mengenai masalah yang sedang dibahas (yang disebut artikel). Tulisan ilmiah berupa artikel biasanya disajikan dengan penjelasan ilmiah dan bukti yang kuat, misalnya data statistik. Jenis tulisan ilmiah atau artikel yang banyak ditemukan di pendidikan tinggi keperawatan saat ini antara lain suatu tinjauan, karangan untuk jurnal, makalah seminar atau hasil pertemuan ilmiah, laporan kasus dan hasil penelitian. Komponen artikel ilmiah umumnya terdiri dari pendahuluan, isipembahasan, dan penutup. Komponen isi karangan sendiri dapat dikembangkan sesuai dengan tujuan penulisan.
\end{abstract}

Kata kunci: jenis artikel, komponen artikel, tulisan ilmiah

\begin{abstract}
Writings can be classified into several types. A feature consists of fact, happening, and processes; an opinion involves one's thought on a subject: and an article discusses the author's toward or his position on one particular subject. A scientific article usually provides scientific explanation and strong evidence such as statistical data. Examples of scientific articles which are frequently encountered in nursing education are a review on a subject, a passage for a journal, seminar articles or a compilation of results of a scientific meeting, a case report, or a study report. The components of scientific article are introduction, discussion, and summary. The content of a discussion varies according to the writing purposes.
\end{abstract}

Key words: article classification, article components, scientific writing 